\title{
Should the Teaching of Biological Evolution Include the Origin of Life?
}

\author{
Antonio Lazcano • Juli Peretó
}

Published online: 8 October 2010

(C) Springer Science+Business Media, LLC 2010

\begin{abstract}
The development of mainstream research on the origin of life as an outcome of Darwinian evolution is discussed. It is argued that prebiotic evolution and the origin of life should not be excluded from the syllabus and should be part of classes on biological evolution, and that the transition from non-living to living matter is best understood when seen as part of evolutionary biology. The wide acceptance of evolutionary approaches to the study of the emergence of life in European and Latin American countries is discussed.
\end{abstract}

Keywords Creationism · Intelligent design · Natural selection · Origin of life · Theory of evolution · Science education

\section{Introduction}

Rice et al. (2010) have critically reviewed some aspects of the analysis of U.S. college students' views on biological evolution published by Paz-y-Miño and Espinosa (2009). In their work, Rice et al. (2010) discuss, in rather convincing terms, the limits of the term "biological

\footnotetext{
A. Lazcano $(\bowtie)$

Facultad de Ciencias,

Universidad Nacional Autónoma de México,

Apartado Postal 70-407, Cd. Universitaria,

04510 México, DF, Mexico

e-mail: alar@ciencias.unam.mx

J. Peretó

Institut Cavanilles de Biodiversitat i Biologia Evolutiva,

Departament de Bioquímica I Biologia Molecular,

Universitat de València,

Apartat Postal 22085,

46071 Valencia, Spain
}

evolution," which underlies the diversity of life both in time and space, and which should not be confused with the concept of "change" that permeates many other areas of scientific inquiry, i.e., the changes in time observed in manifold physical and chemical systems, for instance, which are not akin to biological evolution. Rice et al. (2010) also argue that the theory of evolution, as understood by contemporary life scientists, does not provide an explanation for the origins of life nor requires, to be epistemologically valid, a description how the emergence of the first living systems took place. We show here how Darwin's theory of evolution provided the framework for the development of mainstream scientific explanations of the origins of life by Oparin, Haldane, Urey and others. In contrast to Rice et al. (2010), we suggest that discussing in the classroom how life may have first appeared does not leads to the rejection among students of Darwin's ideas but to a more precise understanding of both the limits and the explanatory power of natural selection.

\section{Darwinian Evolution is Not a Theory of All Kinds of Changes}

It has long been recognized that the proper understanding of the historical development of the theory of evolution requires the acknowledgement of the intellectual atmosphere that led, since the end of the eighteenth century, to a dynamic view of physical, social, economic, and linguistic systems, among others. Many philosophers and naturalists promptly acknowledged that the propensity to extrapolate the processes of biological change and selection to all systems that exhibit change was misguided. It is true that natural selection became part of the literary atmospheres of Emile Zola and Jack London, because evolution and 
progress were identified with one another, and that it also aroused epistemological shivers in a wide range of philosophers and thinkers, from Marx and Engels to Auguste Comte. However, Darwinian evolution is not a theory of all kinds of changes. As suggested by Rice et al. (2010), the recognition that galaxies, languages, and societies, for instance, change and evolve, should not lead to the conclusion they do so by natural selection or other Darwinian mechanisms as biological populations do.

As shown by the success of multi- and interdisciplinary programs like those based on the concept of "astrobiology," the idea of a dynamic universe can lead to significant improvements in science teaching and better comprehension among students of the idea of evolution. The statement "evolution is the language of the cosmos" by Paz-y-Miño and Espinosa (2009) is a wonderful metaphor, but biological evolution has a very precise meaning. Although biology is akin to other fields that depend on a historical perspective, such as cosmology, geology, and comparative planetology, its methodology and premises are different from those of other scientific disciplines. To recall the fortunate expression of Ruse (2006), it is important "to defend Darwin from false (or misguided) friends" that misapply his ideas by extrapolating them to systems were there is no heredity or natural selection.

\section{The Origin of Life: An Ultra vires Issue?}

As Rice et al. (2010) underline, the validity of the theory of biological evolution is independent from a scientific explanation of the origins of life, as Darwin himself acknowledged. Although he had stated in The Origin of Species that "all the organic beings which have ever lived on this Earth may be descended from some primordial form," Darwin was keenly aware that it was not easy to explain how such an ancestral entity had first evolved. Darwin's self-imposed task was the understanding of the evolutionary processes that underlie biological diversity, an issue that is epistemologically independent from explanations of the appearance of life itself (Wilkins and Elsberry 2001; Sarkar 2007). As Darwin wrote in 1839 in his Fourth Notebook (de Beer 1960:180) "My theory leaves quite untouched the question of spontaneous generation" and, as he wrote many years afterwards to the physician George Charles Wallich, "you expressed quite correctly...that I had intentionally left the question of the Origin of Life uncanvassed as being altogether ultra vires in the present state of our knowledge" (de Beer 1959).

Darwin's restrained attitude drew considerable criticism both from friends and foes. "The chief defect of the Darwinian theory is that it throws no light on the origin of the primitive organism - probably a simple cell—from which all the others have descended. When Darwin assumes a special creative act for this first species, he is not consistent, and, I think, not quite sincere..." wrote Haeckel in a footnote in his 1862 monograph on the radiolaria (Haeckel 1862). His criticism was accurate but somewhat surprising, given the boundless admiration that he had for Darwin, but he was not alone in raising the issue. When the German geologist Heinrich George Bronn translated The Origin of Species, in 1860, he did not hesitate to add a chapter of his own in which he discussed spontaneous generation in the context of Darwin's theory. That very same year, Bronn published an essay in which he argued quite emphatically that Darwin's theory would be incomplete until it could account for the origin of life, adding that some observations by Priestley, Pouchet, and others could provide an example of spontaneous generation (Peretó et al. 2009). Darwin, however, acknowledged in several private letters the significance of a natural mechanism for the origin of life, including the 1876 letter to Haeckel where he confessed that "If [spontaneous generation] could be proved true this would be most important to us..." (Darwin 1887).

The enthusiastic support that the concept of panspermia drew among committed evolutionists in the late nineteenth century underlines the independence of the theory of evolution from an explanation for the origin of life. Pasteur's experimental denial of spontaneous generation as an explanation for the ultimate appearance of life led devoted materialists like Hermann von Helmholtz to sidestep the issue by assuming that viable microbes had been delivered to the primitive Earth by meteorites, thus maintaining the significance of evolution (Kamminga 1982; Lazcano 2010a). Toward the end of the nineteenth century, the belief that life on Earth had evolved from extraterrestrial organisms elicited a number of proposed mechanisms that could have transported microbes between planets, but little, if any, attention was given to the central issue of the actual origin of the life forms. With formidable disregard for plausibility, the panspermia hypothesis has been recently resurrected by a number of scientists with a strong commitment to Darwinian evolution, but that have transferred the question of the origin of life to another habitable planet in our galaxy without discussing the actual processes that led to the appearance of such hypothetical extraterrestrial organisms.

A divorce between a materialistic description of evolution and a natural origin of life had major followers among Christian believers towards the end of the nineteenth century. For instance, the Jesuit priest and entomologist Erich Wasmann, who strongly opposed Haeckel's monism, had no issue with a natural evolution of species but used Pasteur's rebuttal of spontaneous generation to argue on the unscientific character of any origin-of-life research. "The 
student of nature... is forced to conclude that only some cause apart from the world could have produced the first living organism out of matter," wrote Wasmann (1910), whose followers during the early twentieth century, when Darwin's ideas on natural selection had undergone a demise, included not only priests but also several Catholic scientists who accepted an evolutionism which excluded the natural origin of life and mind.

In many European and Latin American countries, the struggle for a laical state and a secular society led to major confrontations with the Catholic Church's hierarchy. However, evolution has never been a troublesome issue. The theistic view promoted by the Enlightenment in many European and Latin American countries not only separated religious beliefs from the power structure of the Catholic Church but, equally significant, contributed to develop a secular and evolutionary description of nature and society. There is no formal reference of Darwin or against him in the Vatican Pontifical Magisteria or in the Congregatio (Artigas et al. 2006), and in countries like Mexico public education still bears the secular trademark of the Enlightenment, whose introduction into the country was facilitated by some prominent priests and Jesuits.

In all societies, scientists and students alike vary in their religious beliefs or in the lack of them. In contrast to the situation described by Rice et al. (2010) for the U.S., in other Western societies believers can accept a materialistic explanation for the emergence of life and a Darwinian explanation for the diversity of the biosphere, even if they assume the existence of a divine creator that stipulated the natural laws. In many societies, believers do not necessarily consider religion and science in opposition, and their adherence to Darwinian evolution is not viewed as inconsistent with their faith. Evolution and the origin of life neither disproves nor affirms any particular faith, and we do not know how believers can cope with such issuesand, frankly, we do not care since, after all, religious beliefs are a private issue. It is likely that their inner conflict, if it exists at all, is mellowed by the fact that Catholics, like many other Christian denominations, do not take for granted a literal reading and interpretation of the Bible, and find no problem in accepting two different descriptions of reality, one of which is seen as merely symbolic.

\section{Prebiotic Evolution and the Origin of Life as Open Scientific Issues}

Contemporary discussions on the origin of life are a direct outcome of the Darwinian revolution. The idea that living organisms were the historical outcome of gradual transformations of lifeless matter became widespread soon after the publication of The Origin of Species. This view soon merged with the new fields of biochemistry and cell biology, leading to proposals in which the origin of protoplasm or the appearance of genes and viruses were equated with the origin of life. Some of these hypotheses considered life as an emergent feature of nature and attempted to understand its origin by introducing principles of historical explanation, but most of these explanations went unnoticed, in part because they were incomplete, speculative schemes largely devoid of direct evidence and not subject to fruitful experimental testing (Lazcano 2010a).

Although some of these hypotheses attempted to understand the origin of life by introducing principles of historical explanation, the dominant view was that the first forms of life had been autototrophic microbes, i.e., endowed with the plant-like ability fix atmospheric $\mathrm{CO}_{2}$ and to use it with water to synthesize organic compounds. A major scientific breakthrough occurred, however, when Oparin (1924) suggested instead that primordial life forms had been heterotrophic, i.e., they depended on external sources of carbon compounds and energy for their nourishment, growth and development, a hypothesis that required that prior to the emergence of the first cells a prebiotic synthesis of organic compounds led to the accumulation of the primitive broth.

Oparin's proposal was supported not only by the evidence of organic compounds in meteorites, but also by the striking nineteenth century experimental demonstrations that biochemical compounds such as urea, alanine, and sugars could be formed under laboratory conditions, as had been demonstrated by Wöhler, Strecker and Butlerow, respectively. Oparin's ideas, which were based on his Darwinian credence in a gradual, slow evolution from the simple to the complex, stood in sharp contrast with the then prevalent idea of an autotrophic origin of life. Since a heterotrophic anaerobe is metabolically simpler than an autotrophic one, the former would necessarily have evolved first. Thus, based on the simplicity and ubiquity of fermentative reactions, Oparin (1924) suggested in a small booklet that the first organisms must have been heterotrophic bacteria that could not make their own food but obtained organic material present in the primitive milieu. Somewhat similar ideas were developed independently by other scientists, including R. B. Harvey, C.B. Lipman and, most notably, J. B. S. Haldane (Bada and Lazcano 2003).

Oparin's proposal was a direct outcome of his commitment to a Darwinian perspective. As a young student at the University of Moscow, he joined the laboratory of Alexei $\mathrm{N}$. Bakh, an eminent scientist and political figure at the Karpov Physicochemical Institute. There he worked on photosynthesis and, like most biochemists of his generation, quickly adopted the idea that metabolism was the outcome of oxidation and reduction reactions that were coupled inside cells. By then, Oparin was also a convinced 
evolutionist. As an undergraduate, he had attended the lectures given regularly by Kliment A. Tymiriazev, a renowed plant physiologist, agronomer, and the main advocate of Darwinism in Russia (Lazcano 2010a). Starting in 1865 , Tymiriazev actively promoted Darwin's ideas, an effort that would play a major role in the secularization of Russian society, and that rapidly endeared him to both the liberal and the revolutionary intelligentzia (Vucinich 1988).

Tymiriazev had left the university and, because of his ill health, did not teach but limited his meetings with students and colleagues to small gatherings in his Moscow flat, to which Oparin was rapidly invited. By the time he graduated, Oparin had an academic background that combined natural history, biochemistry, and plant physiology, a knowledge acquired within a research tradition strongly committed to integral approaches in the analysis of natural phenomena. He was not only familiar with nearly all the literature on evolution available in Russia but, perhaps even more important, with the Darwinian method of comparative analysis and historical interpretation of life features (Lazcano 2010a).

In 1936, Oparin published a second volume in Russian with the same title, The Origin of Life, whose English translation became available two years later (Oparin 1938). This book is a masterpiece of evolutionary analysis, and in it, Oparin critically revised his original proposal, arguing for a highly reducing primitive mileu in which iron carbides of geological origin would react with steam to form hydrocarbons. Their oxidation would yield alcohols, ketones, aldehydes, etc., that would then react with ammonia to form amines, amides and ammonium salts. The resulting protein-like compounds and other molecules would form a dilute solution, where they would aggregate to form colloidal systems from which the first heterotrophic microbes evolved. Following Bungenberg de Jong's proposal that the colloid properties of droplets which he termed coacervates formed by the spontaneous aggregation of biological macromolecules could explain the properties of protoplasm, Oparin proposed them as precursors of the first cells (Oparin 1938).

Oparin's book (1938) may be the most significant work ever published on the origin of life (Miller et al. 1997). It is true that many of his original ideas have been superseded. However, over the years, it has become clear that the open character of his theory of chemical evolution has allowed the incorporation of new discoveries and the development of more accurate descriptions of possible primitive scenarios without destroying its overall structure and premises. The heterotrophic theory has not been belittled, for instance, but magnified by the recognition of the key role that genetic polymers must have placed in the origin of life. Perhaps the most important scientific achievements of Oparin may be his insistence that life is the evolutionary outcome of a process and not of a single event, as well as the methodological breakthrough that transformed the study of the origin of life from a purely speculative problem into a workable multidisciplinary research program which has allowed, for instance, an evolutionary interpretation of the catalytic abilities of ribozymes and proposals of the so-called RNA world.

The definition of the problem of the origin of life is certainly different today from what was suggested 80 years ago, when researchers attempted to explain the origin of viral-like genes or the emergence of protoplasm and fermentation. Until a few years ago, for instance, the origin of the genetic code and protein biosynthesis were seen as synonymous with the emergence of life, but this is no longer the case. The significant amounts of evidence supporting the existence of an RNA world suggest, for instance, that at least some of the defining traits of the code are the outcome of Darwinian processes acting over RNAbased life (Yarus 2010).

How the transition between the so-called primitive broth and the RNA world took place is completely unknown and can only be surmised. There are manifold historical records that allow us to reconstruct, with different degrees of precision, the evolutionary processes that preceded life beginning. The available evidence demonstrates that the chemical gap separating organisms from the non-living is not insurmountable, and that the origin of life was the outcome of a natural process. How these different stages unfolded into one another and how life appeared remain open issues, but the mere fact that can address this problem in evolutionary terms is, in itself, an extraordinary demonstration of the importance of a theory based on purely physical and chemical laws that proves the significance of an evolutionary perspective capable of unifying disparate facts and observations from widely different fields within a coherent explanatory framework provided by a Darwinian view.

\section{Physics, Chemistry, and the Emergence of Natural Selection}

A century and a half after Darwin admitted how little was understood about the origin of life, we still do not know when and how the first living beings appeared on Earth. It is difficult to ascertain the earliest traces of life, since most of the rocks from early Archean times that have been preserved have been metamorphosed to a considerable extent. There is no direct evidence of the environmental conditions on Earth at the time of the emergence of life, nor any fossil register of the predecessors of the first cells. Direct information is lacking not only on the chemical composition of the terrestrial atmosphere during the period of the origin of life, but also on other general and local environmental conditions which may (or may not) have been important for the appearance of 
living systems (Bada and Lazcano 2009). Cladistic approaches to the origin of life itself are not feasible, since all possible intermediates that may have once existed have long since vanished. Phylogenetic analyses based on comparative genomics may provide important clues on stages of biological evolution but for the time being, their applicability cannot be extended beyond a threshold that corresponds to a period of cellular evolution prior to the emergence of DNA genomes but in which protein biosynthesis was already in operation, i.e., the so-called RNA/ protein world (Becerra et al. 2007).

As Gould (1995) once wrote, to understand the nature of life, we must recognize both the limits imposed by the laws of physics and chemistry, as well as history's contingency. The many examples of self-organizing physical systems that lead to highly ordered structures demonstrate that, in addition to natural selection, there are other mechanisms of ordered complexity that may have played a role in the origin of living systems. The recognition that the emergence of life is the outcome of an evolutionary process constrained by the laws of physics and chemistry can lead to the acceptance that many properties associated with living systems, such as replication, self-assemblage, or nonenzymatic catalysis are also found in nonliving entities. Some systems may not be "half-alive," but they can exhibit some of the properties we associate with living entities (Lazcano 2010b).

The available evidence suggests that the origin of life and the onset of natural selection resulted from self-organization phenomena involving non-equilibrium physical and chemical processes that go beyond simple Newtonian physics; and were based on the abiotic synthesis, stability, and accumulation of organic molecules endowed with differential reactivity; on nucleic acid self-assembly and chemistry; and the spontaneous assembly of prebiotic amphiphiles into micelles and bilayer membranes, among other processes (de Duve 2005; Lehn 2002; Budin and Szostak 2010). If the emergence of the biosphere is seen as the evolutionary transition between the nonliving and the living, then it is meaningless to attempt to draw a strict line between these two worlds, and the appearance of life on Earth should, therefore, be seen as an evolutionary continuum that seamlessly joins the prebiotic synthesis and accumulation of organic molecules in the primitive environment, with the emergence of self-sustaining, replicative chemical systems capable of undergoing Darwinian evolution (Lazcano 2010b).

\section{Should the Origin of Life Be Included in the Teaching of Biological Evolution?}

It is difficult to accept Rice et al. (2010) that the lack of a detailed explanation of how life appeared leads to a rejection of biological evolution. This may be true in some pious and unworldly circles in the U.S., but it is certainly not the case in countries like Spain and much less in Mexico. Quite surprisingly, no Latin America country was included in the analysis of public acceptance of evolution published by Miller et al. (2006), but Darwin's ideas pose no problem. More than 70 editions of one of Oparin's earliest volumes have been published in Mexico and read by generation after generation of high-school students since it was first translated in 1937. Other books on the origin of life are extremely popular, with one of them having sold over 700,000 copies. Even more important is the nationwide exposure for many decades of Mexico's schoolchildren to evolutionary ideas, from the origin of life to endosymbiosis to natural selection in biological populations, which are included in the textbooks published by the Mexican Secretary of Public Education and provided free to all students. The lessons based on these materials are a preamble to in-depth teaching of evolution in secondary (middle school) and high schools, while in 2007, a reform of the Spanish high school curriculum introduced the teaching of the origin and early evolution of life for all students in a new "Sciences in Contemporary World" (Fabregat et al. 2008).

It is true that creationism and intelligent design are present in many societies (Numbers 2009) but in Mexico, Spain and other countries where Catholicism is part of the cultural background, their influence is quite limited compared to the prosperity they enjoy in the U.S. (Miller et al. 2006). The belief that the Old and New Testaments were literally and verbally inspired is deeply rooted in American mainstream culture (Feldman 2005), and remains a pervasive influence in many aspects of everyday life, including elementary and higher education. (Lazcano 2005). Polls consistently show that in the United States, only a small percentage of citizens hold a secular view of the world, and as underlined by Rice et al. (2010), overwhelming numbers adhere to strict biblical creationism. Some may do so because they are rejecting the possibility that biological evolution explains the origin of life (Rice et al. 2010), but creationism and intelligent design are not religious issues but politics in disguise.

It is not easy for scientists and teachers from other countries to understand the hold that religion has in the U.S., nor the lax attitude of policy-makers in the United States toward the religious right, which manages to influence and sometimes undermine the public educational system; and to prosper there, thanks to a very American vibrant brand of religion. "The wall of separation" between the Church and State may be a guiding principle of American politics, but the huge cultural space that evangelical Protestantism and other politically active religious movements have gained in the United States 
demonstrates how tenuous are the boundaries between the secular and the religious (Lazcano 2005).

Should we shy away from including the origins of life in courses on biological evolution? If not there, where? From the educational perspective, it is risky to leave this issue unattended, as shown by the infamous 2004 statement by Dover High School in Pennsylvania that "Intelligent Design is an explanation of the origin of life that differs from Darwin's view...The school leaves the discussion of Origins of Life to individual students and their families." (Lazcano et al. 2008).

To write that our understanding of the origin and early evolution of life faces major unsolved problems is an understatement. However, the scientific community recognizes them as intellectual challenges and not as requiring metaphysical explanations, as proponents of creationism would have it. This is an important lesson to be taught in the classroom. As in other areas of evolutionary biology, answers to questions on the origin and nature of the first life forms can only be regarded as inquiring and explanatory rather than definitive and conclusive. This does not imply that all origin-of-life theories and explanations can be dismissed as pure speculation, but rather that the issue should be addressed conjecturally, in an attempt to construct not a mere chronology but a coherent historical narrative by weaving together a large number of miscellaneous observational findings and experimental results (Kamminga 1986). Textbooks on cell biology, biochemistry, and molecular biology are peans to a materialistic view of life, and the discussion of the origins of life in the classroom, whether as part of evolutionary biology courses or as separate lectures, can assist the students in understanding that the molecules and structures that underlie the basic properties of cells and organisms are not the outcome of deux ex machina processes but the outcome of evolution.

\section{Conclusions}

Like our colleagues Paz-y-Miño and Espinosa (2009), Rice et al. (2010), and many others, we agree that critical attitudes should be maintained to improve and promote the proper teaching of biological evolution. We are convinced that this task requires the acknowledgement that creationism and intelligent design are political and ideological movements, and not religious issues nor, much less, scientific alternatives. In many Western countries, teachers and pupils alike generally view the framework of intelligent design as a thinly disguised attempt to introduce religious preconceptions into the classroom, and major international efforts are being developed to counteract their negative role in education (Interacademy Panel 2006; Parliamentary Assembly of the Council of Europe 2007). However, it would be unwise to simply sit back and watch with incredulity as our American colleagues struggle against intelligent design creationists and other fundamentalisms.

There are manifold indications that the creationism movement has been flexing its muscles and starting to proselytize far and wide. Its potential threat to science education in many countries should not be underestimated, as shown by the increased influence of fundamentalist Evangelical churches among Mexican immigrants in the U.S. and their South American counterparts in Spain and Italy, where conservative religious groups provide haven and support against the isolation that immigrants have to suffer in societies that have not yet been able to incorporate them in full (Lazcano 2007). However, the support of these fundamentalist groups comes with a tag, which includes literal reading of some holy texts and, in many cases, notso-subtle campaigns against the teaching of evolution. Limiting the spread of creationism must not involve restrictions of religious freedom, but should address instead pending problems that include (a) the absence of evolutionary biology in the curricula of medical, veterinary and other life sciences studies; (b) the growth and expansion of U.S. fundamentalist churches into Asia, Latin America, and several European countries; and (c) equally important, unfortunate weakening of educational institutions and the social disdain of the role of teachers and schools that we are suffering at a worldwide level.

Acknowledgments Support from a UC Mexus-CONACYT Fellowship and from the DGAPA-UNAM to AL is gratefully acknowledged. AL is indebted to Professor Amparo Latorre, and Professor Andrés Moya, of the Institut Cavanilles de Biodiversitat i Biologia of the Universitat de Valencia, for financial support of a Prometeo Grant and their warm hospitality. Financial support by grants BFU2006-01951/BMC from the Spanish Ministry of Science and Innovation and FP7-KBBE-2007212894 (TARPOL project, European Union) to JP is gratefully acknowledged.

\section{References}

Artigas M, Glick T, Martinez R. Negotiating Darwin: the vatican confronts evolution 1877-1902. Baltimore: John Hopkins; 2006.

Bada JL, Lazcano A. Prebiotic soup: revisiting the Miller experiment. Science. 2003;300:745-6.

Bada JL, Lazcano A. The origin of life. In: Ruse M, Travis J, editors. The Harvard companion of evolution. Cambridge: Belknap/ Harvard University Press; 2009. p. 49-79.

Becerra A, Delaye L, Islas S, Lazcano A. Very early stages of biological evolution related to the nature of the last common ancestor of the three major cell domains. Annu Rev Ecol Evol Syst. 2007;38:361-79.

Budin I, Szostak JW. Expanding roles for diverse physical phenomena during the origin of life. Annu Rev Biophys. 2010;39:245-63.

Darwin F. The life and letters of Charles Darwin, including an autobiographical chapter. London: John Murray; 1887. p. 180.

de Beer G. Some unpublished letters of Charles Darwin. Notes \& Records of the Royal Society, London. 1959;14: 12-66 
de Beer G. Darwin's notebooks on transmutation of species, part IV, fourth notebook. Bull Brit Mus Hist Ser. 1960;2:151-83.

de Duve C. The onset of selection. Nature. 2005;433:581-2.

Fabregat J, Peretó J, Sapiña F, García PJ, Ramón D, Edwards M, et al. Ciencias para el mundo contemporáneo. Paterna: Editorial ECIR; 2008.

Feldman N. Divided by God: America's church-state problem-and what we should do about it. New York: Farrar Straus and Giroux; 2005.

Gould SJ. What is life? as a problem in history. In: Murphy MP, O’Neill LA, editors. What is Life? The next 50 years. Cambridge: Cambridge University Press; 1995. p. 25-39.

Haeckel E. Die radiolarien rhizopoda radiaria eine. Monographie. Berlin: Druck und Verlag Von Georg Reimer; 1862.

Interacademy Panel on International Issues. IAP statement on the teaching of evolution; 2006. http://www.interacademies.net/Object. File/Master/6/150/Evolution\%20statement.pdf.

Kamminga H. Life from space-a history of panspermia. Vistas Astron; 1982. 26 p. $67-86$

Kamminga H. Historical perspective: the problem of the origin of life in the context of developments in biology. Orig Life Evol Biosph. 1986;18:1-10.

Lazcano A. Teaching evolution in Mexico: preaching to the choir. Science. 2005;310:787-9.

Lazcano A. Pedro Picapiedra y el diseño inteligente: hacia una teología de supermercado. Bol Soc Esp Bioquim Biol Mol. 2007;153:5-7.

Lazcano A. Historical development of origins of life. In: Deamer DW, Szostak J, eds, Perspectives in Biology: The Origins of Life. Cold Spring Harbor; 2010a; p. 1-16

Lazcano A. Which way to life? Orig Life Evol Biosph. 2010b;40:161-7.

Lazcano A, Becerra A, Peretó J. Evolutionary theory: it's on the school syllabus in Mexico. Nature. 2008;453:719.

Lehn JM. Towards self-organization and complex matter. Science. 2002;295:2400-3.
Miller SL, Schopf JW, Lazcano A. Oparin's “Origin of Life”: 60 years later. J Mol Evol. 1997;44:351-3.

Miller JD, Scott EC, Okamoto S. Public acceptance of evolution. Science. 2006;313:765-6.

Numbers RL. Myth 24 that creationism is a uniquely American phenomenon. In: Numbers RL, editor. Galileo goes to jail and other myths about science and religion. Cambridge: Harvard University Press; 2009. p. 215-22.

Oparin AI. Proiskhozhedenie Zhizni Moscow: Mosckovskii Rabochii, 1924 Reprinted and translated. In: Bernal JD, editor. The origin of life. London: Weidenfeld and Nicolson; 1924.

Oparin AI. The origin of life. New York: MacMillan; 1938.

Parliamentary Assembly of the Council of Europe. The dangers of creationism in education. 2007. http://assembly.coe.int/main.asp? link=/documents/workingdocs/doc07/edoc11297.htm.

Paz-y-Miño G, Espinosa A. Acceptance of evolution increases with student academic level: a comparison between a secular and a religious college. Evo Edu Outreach. 2009;2:655-75.

Peretó J, Bada JL, Lazcano A. Charles Darwin and the origins of life. Orig Life Evol Biosph. 2009;39:395-406.

Rice JW, Warner DA, Kelly CD, Clough MP, Colbert JT. The theory of evolution is not an explanation for the origin of life. Evo Edu Outreach. 2010;3:141-2.

Ruse M. Darwinism and its discontents. New York: Cambridge University Press; 2006.

Sarkar S. Doubting Darwin? Creationist designs on evolution. Malden: Balckwell Publishing; 2007.

Vucinich A. Darwin in Russian thought. Berkeley: University of California Press; 1988.

Yarus M. Life from an RNA world: the ancestor within. Cambridge: Harvard University Press; 2010.

Wasmann E. Modern biology and the theory of evolution. London: Kegan Paul Trench Trübner \& Co; 1910. p. 269.

Wilkins JS, Elsberry WR. The advantages of theft over toil: the design inference and arguing from ignorance. Biol Philos. 2001;16:711-24. 